\title{
AUTONOMOUS DRIVING ALGORITHMS IN SCALED
}

\section{ENVIRONMENT}

\section{GABRIELA ACHTENOVÁ}

Josef Božek Research Centre of Engine and Automotive Technology, Czech Technical University in Prague, Technická 4, 16607 Prague 6, Czech Republic, E-mail: gabriela.achtenova@fs.cvut.cz

\section{ONDREJ KOREC}

Czech Technical University in Prague, Faculty of Mechanical Engineering

\section{SHRNUTí}

Článek se zabývá zhodnocením vývoje projektu SMALL na ČVUT v Praze, který se týkal zkoušek systémů vedoucí k autonomnímu navádění vozidel. Pomocí zmenšeného modelu vozidla byly odzkoušeny algoritmy adaptivního tempomatu, včetně systému Stop\&Go a sledování trajektorie vpředu jedoucího vozidla. Pomocí podobnostního teorému je možné výsledky přepočítat na skutečné vozidlo a předpovídat tak chování vozidla v koloně, či stabilitu kolony vozidel.

\section{KLíČOVÁ SLOVA: ZMENŠENÝ MODEL VOZIDLA, ADAPTIVNII TEMPOMAT, SLEDOVÁNÍ TRAJEKTORIE PILOTNÍHO VOZIDLA}

\section{ABSTRACT}

The article gives a brief overview about the evolution of the SMALL project at Czech Technical University in Prague. The work was dedicated to test control algorithm, for autonomous drive of vehicles. With help of scale model the algorithms of Adaptive Cruise Control were tested, including Stop\&Go System and the following of path of leading vehicle. With help of Buckingham PI theorem of similarity is possible to recalculate the obtained results to the real vehicle and predict the behavior of vehicle in the platoon, or the stability of a platoon.

\section{KEYWORDS: SCALED MODEL, ADAPTIVE CRUISE CONTROL, PATH FOLLOWING OF LEADING VEHICLE}

\section{INTRODUCTION}

The SMALL project (Scaled Mobility on Laboratory Level) was started by prof. Joop Pauwelussen on HAN University in the Netherlands [1]. The target of the project was to built an educational tool which will enable to test and understand the intelligent transport system at low-budget level. Czech Technical University in Prague joined this project and developed its own scaled vehicle [2]. However the control part of scaled vehicle of Czech Technical University was during last year completely changed, as well as the control environment on the supervising computer. The vehicle is described in next chapter. Further are summarized the results achieved in last year in frame of a master thesis [3], which was focused on testing of adaptive cruise control with Stop\&Go system. Finally we will describe the tests of algorithm of following the trajectory of leading vehicle. These tests were carried out in frame of a bachelor thesis [4].

\section{SMALL VEHICLE}

The model has a chassis with twin-wishbone axles, inflatable tyres (exchangeable for rubber tyres), disc brakes on all wheels with servos actuating the hydraulic pressure for brake operation separately on every wheel, and a servo for steering and driving electromotor Satrema SA2420 with its own controller JETI model JES045 DC. The vehicle can be coupled with one or two axle trailers equipped with their own sensors. Notwithstanding in the present article all results are acquired with single vehicle only. The description of trailer and semi-trailer can be found in [5]. As a control and data acquisition unit was chosen NI SbRIO with respect of ease of use and programming, low weight and good customer and academic support from National Instruments (NI). $\mathrm{NI}$ Single-Board RIO is one of the devices of RIO platform that combines deployable, embedded devices that feature a realtime processor, reconfigurable field-programmable gate array, and analog and digital I/O on a single board programmed with NI LabView software. The SbRIO is used for data acquisition and PWM control of servo actuators. All data are sent to the 
supervising computer, which decides about the main control of the vehicle movement; because it is running the algorithm for autonomous drive. For sending the data to the supervising computer wireless access point LinkSys WAP54G is used.

The movement of the vehicle is sensed by optocouplers used for sensing the revolutions of each wheel and electric motor. To monitor the behavior of the vehicle in longitudinal and lateral direction, SMALL is further equipped with bi-axial accelerometers ADXL203 and yaw-rate. Last named sensors are placed in the center of gravity of the vehicle.

The energy supply is solved with using two $\mathrm{Pb}$ accumulators $12 \mathrm{~V}$; 0,8 A.h and two NiMH accu-packs SunPower 4000 7,2 V; 4 A.h which are supplying two voltage levels $24 \mathrm{~V}$ for SbRIO device with the actuators and auxiliary devices and 14,4 V for JESO45 regulator and electric driving motor. The $5 \mathrm{~V}$ necessary for some sensors and servo actuators is provided with help of DC-DC converter Lambda PXF40-12S05. Further two additional DC-DC miniconverter switching regulators of LM 2576T-5 were made.

\section{ADAPTIVE CRUISE CONTROL (ACC)}

The first target was to compare the behaviour of full scale vehicle (FSV) equipped with ACC with behaviour of scaled vehicle SMALL. The bibliographic search of ACC algorithm is presented in [3]. For testing on SMALL vehicle was finally chosen the algorithm proposed by Ondrej Laník, which was tested on FSV during preparation of PhD thesis, and where the complete algorithm with all tuning constant is known. The description of the used algorithm can be found in [6]. To compare the results between experiments and simulations done for FSV with experiments and simulations done for SMALL the Buckingham similarity theorem was used. This theorem says that when two systems can be described by one model, then for both systems can be used the same non-dimensional equations and both systems are dynamically similar.

For the fuzzy ACC controller were chosen two inputs: relative speed - see equation (1), and headway distance error (2).

$D V=v_{l}-v_{f}$

$\Delta R_{h}=\left(\frac{x_{l}-x_{f}}{v_{f} \cdot T_{h}} \cdot 100\right)-100$

Where $x_{l}\left(x_{f}\right)$ signifies longitudinal position of leading (following) vehicle, $v_{l}$ and $v_{f}$ mean velocity of leading and following vehicle, $T_{h}$ is headway time.

The output from the controller is the desired acceleration within a limited range. Within a fuzzy ACC-controller the inputs are divided using Gauss membership functions into linguistic values.
Inside fuzzy ACC controller is a set of 25 rules. During the tests described in [6] the controller did not work properly in cases when the following vehicle lost the contact with leading vehicle. Therefore the controller was extended by three inputs: cruising speed, target presence and visible distance. Totally was prepared a system with 34 rules. The algorithm was tested with several scenarios on Dutch highways. This extended fuzzy controller we used for test in SMALL vehicle.

For our experiments we recalculated the membership functions to values achievable with SMALL vehicle and converted the desired accelerations from ACC to real control signal for available actuators. The tests were performed mostly indoor. The environment for testing includes two vehicles. One is SMALL model with implemented ACC algorithm and second is preceding vehicle - simple radio controlled model without any sensors - see Figure 4 . With regards to the available equipment in time of experiments we could perform only the following tests:

1. Total stop of the vehicle in front of the obstacle (test of Stop\&Go functioning).

2. "Closing" scenario. The SMALL vehicle approaches the leading vehicle cruising at constant speed. This scenario is characteristic with the transition to constant-speed following. To perform the ACC test the SMALL vehicle is equipped with laser range sensor Banner LT3PI. To be able to use the maximal range of sensor the obstacle for first test was covered with reflexive material.

The results of both performed test are depicted in the following Figures. The results from the first test in Figure 1 show the comparison between the experimentally sensed and simulated data. The second test compares the experimentally measured data from FSV which were scaled down to SMALL with data acquired during SMALL tests. The peaks in SMALL data in vehicle velocity measurements can be explained from low precision of optocouplers. In all cases both systems show quite similar performances, which proves that the SMALL vehicle can be used as device for simulating the FSV behaviour.

\section{FOLLOWING OF TRAJECTORY OF LEADING VEHICLE}

To perform the tests of following the trajectory the SMALL vehicle was equipped with MSI MIN StarCampClip webcamera mounted perpendiculat to the longitudinal axis in front of the vehicle.

For data transmission between the web camera and supervising computer was used router TP-Link type tl-ps310u with speed of $54 \mathrm{Mbit} / \mathrm{s}$. First was experimentally verified the angle of view of the camera. 

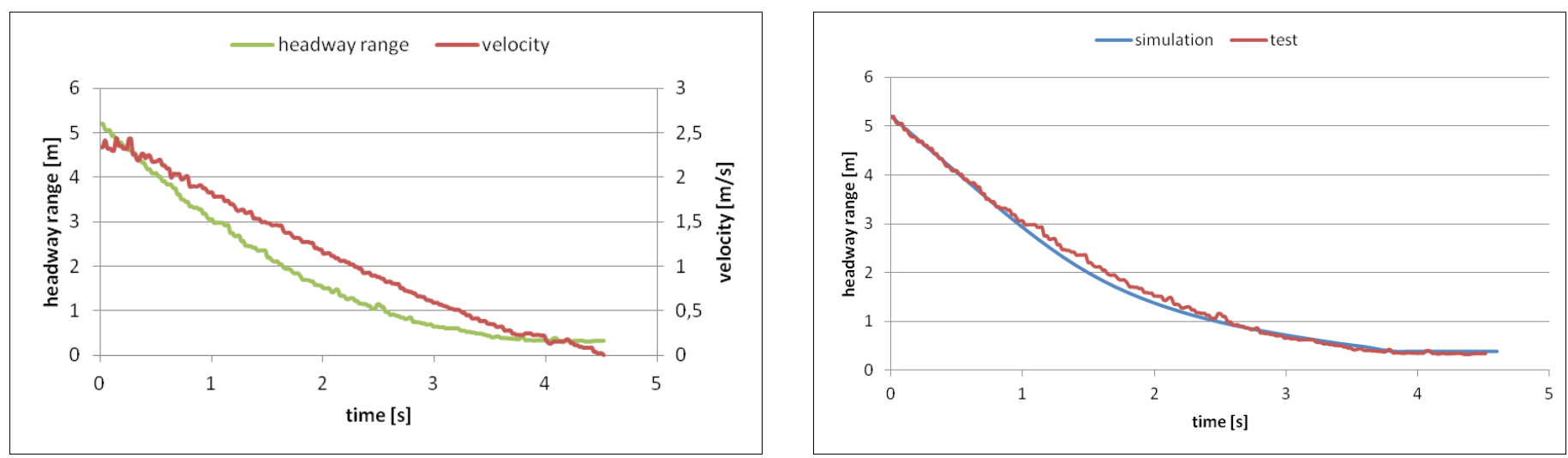

FIGURE 1: Test 1; Closing to the fixed obstacle. Left graph monitors the behaviour of SMALL vehicle, the right graph presents the comparison between simulation and experimental data. The test was performed for desired Headway time $T_{h}=1,3 \mathrm{~s}$.

OBRÁZEK 1: Test 1; Zastavení před překážkou. Levý graf ukazuje chování vozidla SMALL, zatímco na pravém grafu je vidět srovnání mezi simulací a experimentem. Test by proveden při zvolené vzdálenosti $\mathrm{T}_{h}=1,3 \mathrm{~s}$.
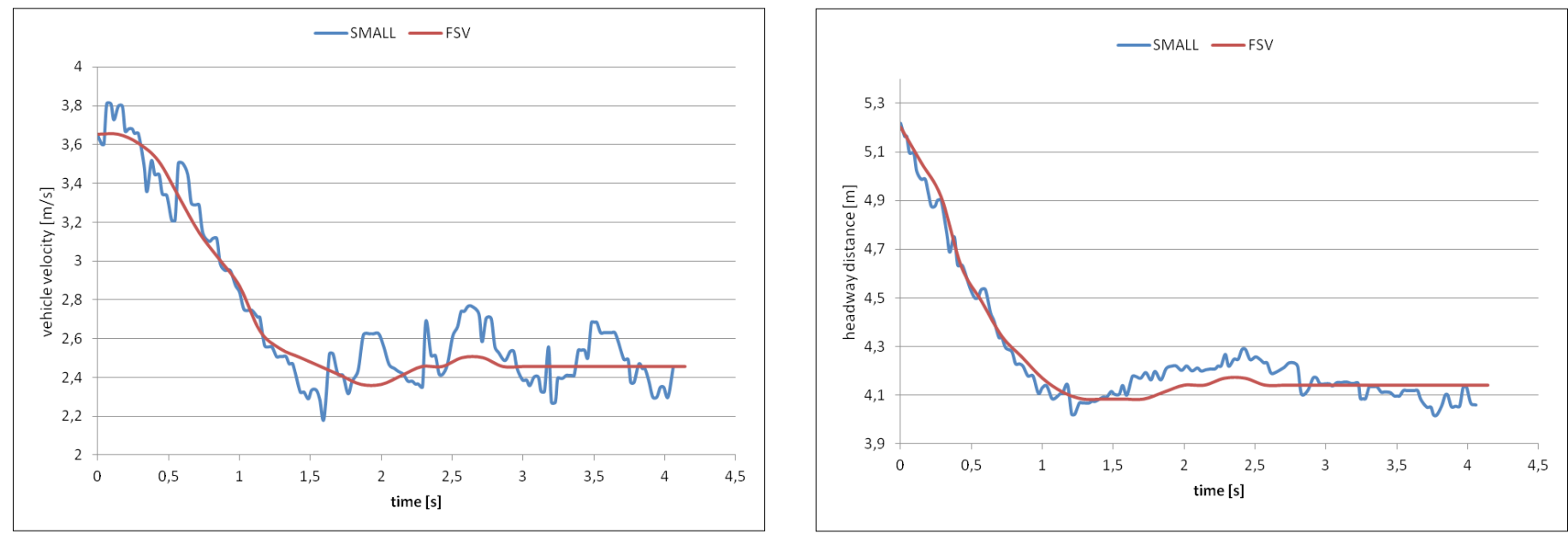

FIGURE 2: Test 2; Closing scenario. Left: Comparison of scaled FSV and SMALL velocities. Right: Comparison of scaled FSV and SMALL headway distances. OBRÁZEK 2: Dojezd vozidla. Vlevo: porovnání přepočítané rychlosti skutečného vozu a vozu SMALL. Vpravo: Porovnání vzdálenosti od vpředu jedoucího vozidla pro skutečné vozidlo a SMALL.

To simplify the recognition of leading vehicle, it was equipped with rectangular plate with distinct and well defined longitudinal center edge. In reality it corresponds to the wings of rear trailer doors.

As input value for control algorithm was used the evaluation $p$ of position of the center edge of the rectangular plate from the left edge of the image $x_{s}$ to the total width of image $s$.

$p=\frac{x_{s}}{s}$

The output value for steering servo control is evaluated from the following equation, which is based on calculation of angle under which the web camera observes the center edge. The equation takes into account the angle of vision of web camera $\alpha$, position of center edge $p$ and tuning coefficient $k$.
$O U T=k \cdot \arctan \left((p-0,5) \cdot \tan \frac{\alpha}{2}\right)$

The algorithm implemented in LabView - module IMAQ Vision is used for evaluation of center edge.

During the practical test the biggest disadvantage was the low computational power of supervising computer, which causes also the slowing-down of data acquisition. The maximal achievable speed was 10 images/s, which imposes than also the limit of speed of SMALL vehicle movement to $1,5 \mathrm{~m} / \mathrm{s}$. For test was prepared a path with several obstacles. The speed of SMALL and of leading vehicle was kept constant. In Figure 3 are demonstrated the first results of path following.

From Figure 3 can be seen that for sharp curves the deviation in path equals approximately half of the wheel width of the vehicle. Such deviation is in reality absolutely inadmissible. 
The suggested path following algorithm should be treated as premature experiment for testing the functioning of sensors, data transmission and image processing. The algorithm with more reliable results is under development.

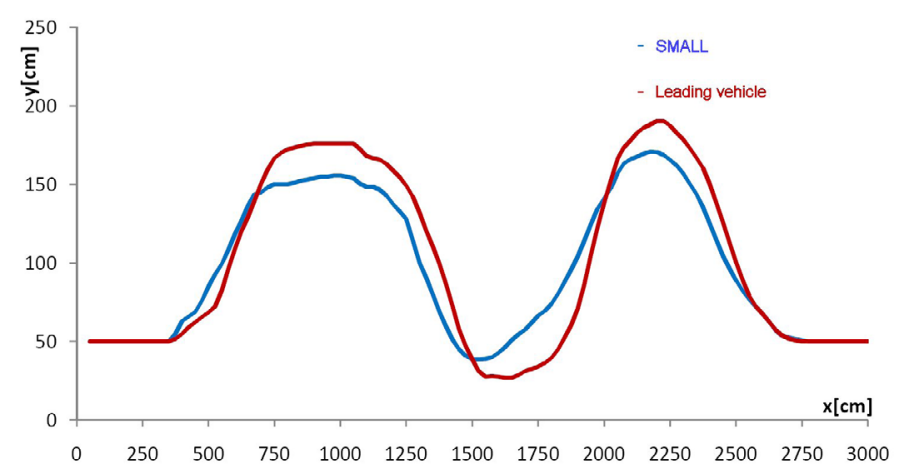

FIGURE 3: Trajectory of leading and following (SMALL) vehicle.

OBRÁZEK 3: Trajektorie dráhy vedoucího a sledujícího (SMALL) vozidla.

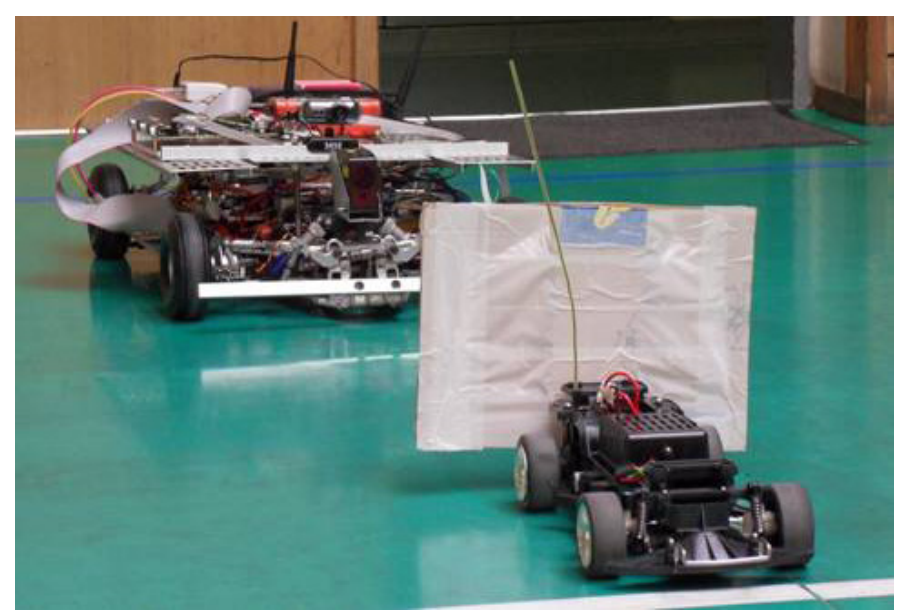

FIGURE 4: Illustrative photo of leading radio controlled vehicle with following SMALL vehicle behind.

OBRÁZEK 4: Ilustrativní obrázek pilotního rádiem řízeného modelu sledovaného vozem SMALL.

\section{CONCLUSIONS}

The SMALL project was started with objective to develop a tool which will:

- Help the understanding of intelligent transport systems at an easy to handle and low-budget level

- Serve as an educational tool to motivate students in interdisciplinary research in this challenging field.

SMALL remains to be an educational tool which is completely maintained and developed by students in frame of their bachelor or master thesis.

With tests results we proved that both objectives can be fulfilled. The possibility of prediction of behavior of FSV based on the measurements made on SMALL was confirmed. SMALL is valuable, low budget tool especially for systems testing autonomous driving and following of the leading.

\section{ACKNOWLEDGEMENTS}

The project is performed at Czech Technical University in Prague (CTU) in collaboration with Hogeschool van Arnhem en Nijmegen (HAN), Arnhem in the Netherlands. The research on Czech Technical University has been subsidized by the Czech Ministry of Education Project 1M0568 Josef Božek Research Center. The support is gratefully acknowledged.

\section{LIST OF ABBREVIATIONS}

ACC Adaptive Cruise Control

FSV Full Scale Vehicle

HAN Hogeschool van Arnhem en Nijmegen

$\mathrm{NI} \quad$ National Instruments

SbRIO Single-board RIO

SMALL Scaled Mobility on Laboratory Level

\section{REFERENCES}

[1] Pauwelussen J.P. (2003). Memorandum: SMALL (Scaled Mobility At Laboratory Level)

[2] Achtenová G. \& Pauwelussen J. (2007). A SMALL Note Short Communication. Mecca. 5(1), p. 11-14.

ISSN 1214-0821.

[3] Korec 0. (2011). SMALL - Control Unit + ACC with Stop\&Go. Unpublished Master thesis, HAN University. Arnhem, The Netherlands and CTU in Prague, Czech Republic.

[4] Škopek M. (2011). Autonomní jízda zmenšeného modelu SMALL. Unpublished bachelor thesis, Czech Technical University in Prague.

[5] Kvapil V. (2004). Scaled model of articulated vehicle. Unpublished master thesis, Czech Technical University in Prague.

[6] Láník 0. (2004). Fuzzy Logic Adaptive Cruise Control Controller with Extended Adaptive Functions. MECCA. 2(4), p. 16-23. ISSN 1214-0821. 


\title{
SUBSCRIPTION INFORMATION \\ FOR YEAR 2012
}

\section{MECCA IS PUBLISHED THREE TIMES A YEARR}

* Middle European countries profit special price..... 200 CZK

(in Czech crowns) without shipping costs per issue.

* Price for rest of world. $15 €$ per issue without shipping costs.

* Price for annual subscription including shipping costs for Czech republic $760 \mathrm{CZK}$

* Price for annual subscription including shipping costs for other middle European countries $860 \mathrm{CZK}$

* Price for annual subscription including shipping costs for the rest of Europe $.56 €$

* Price for annual subscription including shipping costs for the overseas

\section{PLEASE PAY THE AMOUNT ON THE FOLLOWING BANK ACCOUNT:}

\begin{tabular}{|c|c|}
\hline Name of account: & CVUT V PRAZE - FAKULTA STR \\
\hline \multirow{3}{*}{ Address of account owner: } & Technická 4 \\
\hline & 16607 Praha 6 \\
\hline & Czech Republic \\
\hline Account number: & $27-4095990227$ \\
\hline Bank code: & 0100 \\
\hline \multirow[t]{4}{*}{ Bank address: } & Komerční banka a.s., Praha 6 \\
\hline & Dejvická 52 \\
\hline & 16059 Praha 6 \\
\hline & Czech Republic \\
\hline Variable symbol: & 241 \\
\hline
\end{tabular}

\section{FOR ALL QUESTIONS, PLEASE, CONTACT THE EDITOR:}

\author{
Gabriela Achtenová \\ Czech Technical University in Prague \\ Technická 4, 16607 Praha 6 \\ Czech Republic \\ Tel.: +4202243524 99, Fax: +420224352500 \\ mecca@fs.cvut.cz \\ gabriela.achtenova@fs.cvut.cz
}

\section{LIST OF COUNTRIES PROFITIING THE SPECIAL PRICE OF MECCA:}

Czech Republic, Slovakia, Poland, Hungary, Romania, Bulgaria, Former USSR republics, Former Yugoslav republics 